\title{
Effect of hCG, cAMP and FSH on steroidogenesis by human corpora lutea in vitro
}

\author{
Morag G. Hunter* and T. G. Baker $\dagger$ \\ Centre for Reproductive Biology, University of Edinburgh, Department of Obstetrics and \\ Gynaecology, 37 Chalmers Street, Edinburgh, EH3 9EW, U.K.
}

\begin{abstract}
Summary. Human corpora lutea of various ages were minced and incubated in the. presence of hCG $(10$ i.u./ml), cAMP $(10 \mathrm{mM})$ or FSH $(20 \mathrm{mu} / \mathrm{ml})$ and production of progesterone and oestradiol was measured. Cyclic AMP and hCG stimulated progesterone and oestradiol production during at least the mid-and late luteal phases, but FSH stimulated only oestradiol production during the early and mid-luteal phases and had no effect on progesterone production. This demonstrates that progesterone and oestradiol synthesis by the human corpus luteum can be independently controlled.
\end{abstract}

\section{Introduction}

The human corpus luteum is unusual in that it has the ability to synthesize and secrete both progesterone and oestradiol (Hammerstein, Rice \& Savard, 1964; Savard, Marsh \& Rice, 1965; Mikhail, 1970; Abraham, 1974; Baird \& Fraser, 1974; Baird, Baker, McNatty \& Neal, 1975). This has been attributed to the fact that the human corpus luteum consists of both granulosa and theca lutein cells (Corner, 1956), whereas in most non-primate species the corpus luteum is predominantly made up of granulosa lutein cells (Savard et al., 1965). The factors controlling steroidogenesis and thus the lifespan of the human corpus luteum have not yet been fully elucidated, although human chorionic gonadotrophin (hCG) and luteinizing hormone (LH) are reported to stimulate progesterone synthesis in vivo and in vitro (Rice, Hammerstein \& Savard, 1964; Santos \& Hermier, 1973; Marsh \& LeMaire, 1974; Dell'Acqua et al., 1976), and infusion of LH alone is sufficient to maintain the corpus luteum in vivo (Vande Wiele et al., 1970). The present study was carried out to examine the effect of hCG and follicle-stimulating hormone (FSH) on the production of progesterone and oestradiol by fragments of human luteal tissue incubated in vitro. FSH was of particular interest because of reports that follicular aromatization can be controlled by FSH (Moon, Dorrington \& Armstrong, 1975; Armstrong \& Dorrington, 1977; Erickson \& Hsueh, 1978).

\section{Materials and Methods}

\section{Tissue collection and incubation}

Corpora lutea (CL) were obtained throughout the luteal phase from women undergoing surgery for various non-endocrine disorders, e.g. menorrhagia, fibroids or tubal ligation. All patients gave full and informed consent. The stage of the menstrual cycle was assessed from the

* Present address: Department of Biochemistry, Royal Free Hospital School of Medicine, University of London, 8 Hunter Street, London, WC1N 1BP, U.K.

+ Present address: School of Medical Sciences, University of Bradford, Bradford, West Yorkshire, U.K. 
date of the last menstrual period; endometrial and luteal histology; plasma concentrations of LH, FSH, progesterone and oestradiol; and steroid content of the luteal tissue. The CL were assigned to three groups: early (Days 1-5), mid- (Days 6-10) and late (Day 11-menstruation) luteal phase, with Day 1 being the day of ovulation.

When removed from the ovary the CL was immediately placed in a sterile universal container on ice and transported to the laboratory. The tissue was then minced finely with two scalpel blades and washed in $50 \mathrm{ml}$ Eagle's minimum essential medium with Earle's salts (EMEM)(Eagle, 1959) and supplemented with Hepes buffer $(20 \mathrm{~mm})$ (both Flow Laboratories, Irvine, U.K.) to remove much of the blood clot. The interval between removal of the CL and washing was always less than $30 \mathrm{~min}$. The tissue was then weighed into aliquots of approximately $20 \mathrm{mg}$ (wet weight) into glass scintillation vials, and $2 \mathrm{ml}$ EMEM plus Hepes buffer ( $\mathrm{pH} \mathrm{7.3)} \mathrm{were} \mathrm{added} \mathrm{to} \mathrm{each} \mathrm{incubate.} \mathrm{The} \mathrm{control} \mathrm{and} \mathrm{treatment} \mathrm{incubations} \mathrm{of} \mathrm{tissue}$ from each $\mathrm{CL}$ were always carried out at least in quadruplicate to ensure that representative parts of the CL were being studied. Similarly, at least four tissue aliquots were frozen immediately after weighing and stored at $-20^{\circ} \mathrm{C}$ until subsequent determination of the original steroid concentration in the tissue.

Dibutyryl cAMP and hCG (both from Sigma Chemical Co., Poole, Dorset, U.K.) were added to the incubations to give final concentrations of $10 \mathrm{~mm}$ and $10 \mathrm{i} . \mathrm{u} . / \mathrm{ml}$ respectively, and human FSH (Butt CPDS; 165000 i.u./mg, containing $<0.1 \% \mathrm{LH}$ ) was added to give a final concentration of $20 \mathrm{mu} / \mathrm{ml}$. After gassing for $10 \mathrm{sec}$ with $95 \% \mathrm{O}_{2} / 5 \% \mathrm{CO}_{2}$, each vessel was sealed and incubated for $3 \mathrm{~h}$ in a shaking water bath at $37^{\circ} \mathrm{C}$. At the end of the incubation the tissue was separated from the medium by centrifugation $(5 \mathrm{~min}$ at $100 \mathrm{~g}$ ) and homogenized in absolute alcohol. The tissue extract and medium were assayed for progesterone and oestradiol as described below.

\section{Radioimmunoassays}

Progesterone. This assay was based on the methods of Scaramuzzi, Corker, Young \& Baird (1975) and the antiserum was raised in a sheep to a progesterone 11 $\alpha$-hemi-surccinate-bovine serum albumin conjugate. The antiserum showed negligible cross-reactivity with androgens and oestrogens $(<0.1 \%)$ and also with $20 \alpha$ - and $20 \beta$-dihydroprogesterone $(<1 \%)$. The validity of the direct assay of culture medium and ethanolic extractions (dried and re-dissolved in phosphate buffer) was checked by comparing values obtained by this method with values for aliquots taken from the same samples and extracted with petroleum ether. Regression analysis of the results gave a coefficient of correlation of $r=0.99(n=15)$ for media, and $r=0.98(n=18)$ for tissue extracts. The limit of sensitivity of the assay was $25 \mathrm{pg} /$ tube at $90 \%$ binding, the interand intra-assay coefficients of variation were $14.8(n=40)$ and $7.9 \%(n=24)$ respectively, determined in separate repeated assays, and repeated measures of a single sample within the same assay.

Oestradiol-17 $\beta$. The antiserum was raised in a goat to a conjugate of 6-O-carboxymethyloxime derivative of 6-keto-oestradiol and bovine serum albumin. This antiserum had low cross-reactivity with other oestrogens (oestradiol-17a, $1 \%$; oestrone, $5 \%$, oestriol, $<0.001 \%$ ) and the minimum detectable amount of oestradiol was $5 \mathrm{pg} /$ tube. Regression analysis of extracted (with ether) and non-extracted media and tissue extracts gave a coefficient of correlation of $r=0.97(n=18)$ for media and $r=0.95(n=16)$ for tissue extract. The interand intra-assay variations were $14.9(n=20)$ and $5.4 \%(n=24)$ as described above.

\section{Results}

Steroid production during incubation was calculated by subtracting the mean of the concentration in each particular CL before incubation from the sum of the steroid in both the tissue and media of each incubate after incubation. 
As shown in Table 1, there was much variation both within and between CL, but hCG significantly stimulated progesterone production at all stages of the luteal phase, and oestradiol significantly in the mid- and late luteal phases. The early luteal tissue was the most synthetically active in terms of control amounts of steroid synthesized per $g$ wet weight tissue, and the late luteal phase tissue was still capable of responding to gonadotrophic stimulation.

Table 1. Effects of hCG, cAMP and FSH on production of progesterone and oestradiol by corpora lutea from women in the early, mid- and late luteal phase of the menstrual cycle

\begin{tabular}{|c|c|c|c|c|c|c|c|c|c|}
\hline & \multicolumn{3}{|c|}{ hCG (10 i.u./ml) } & \multicolumn{3}{|c|}{ cAMP (10 mM) } & \multicolumn{3}{|c|}{ FSH $(20 \mathrm{mu} / \mathrm{ml})$} \\
\hline & Early & Mid & Late & Early & Mid & Late & Early & Mid & Late \\
\hline No. of CL & 5 & 7 & 7 & 3 & 4 & 4 & 3 & 5 & 5 \\
\hline $\begin{array}{l}\text { Total no. of incubations } \\
\text { Progesterone }\end{array}$ & 52 & 72 & 64 & 30 & 42 & 34 & 30 & 46 & 44 \\
\hline Original content $(\mu \mathrm{g} / \mathrm{g})$ & $\begin{array}{c}5 \cdot 6 \\
\pm 1.9\end{array}$ & $\begin{array}{l}10.8 \\
\pm 1.9\end{array}$ & $\begin{array}{c}3.8 \\
\pm 0.8\end{array}$ & $\begin{array}{c}6.8 \\
\pm 2.8\end{array}$ & $\begin{array}{l}10 \cdot 8 \\
\pm 2 \cdot 7\end{array}$ & $\begin{array}{c}2.3 \\
\pm 0.8\end{array}$ & $\begin{array}{c}8 \cdot 3 \\
\pm 4 \cdot 2\end{array}$ & $\begin{array}{l}8 \cdot 3 \\
\pm 1.9\end{array}$ & $\begin{array}{l}3.0 \\
\pm 0.7\end{array}$ \\
\hline $\begin{array}{l}\text { Control production } \\
(\mu \mathrm{g} / \mathrm{g} / 3 \mathrm{~h})\end{array}$ & $\begin{array}{c}5 \cdot 2 \\
\pm 1.5\end{array}$ & $\begin{array}{c}2.2 \\
\pm 0.5\end{array}$ & $\begin{array}{c}3.6 \\
\pm 0.9\end{array}$ & $\begin{array}{c}8 \cdot 2 \\
+2 \cdot 3\end{array}$ & $\begin{array}{c}2 \cdot 3 \\
\pm 0.5\end{array}$ & $\begin{array}{c}1.6 \\
\pm 0.3\end{array}$ & $\begin{array}{l}10 \cdot 1 \\
\pm 6.2\end{array}$ & $\begin{array}{c}2.9 \\
\pm 0.5\end{array}$ & $\begin{array}{l}2.0 \\
\pm 0.5\end{array}$ \\
\hline $\begin{array}{l}\text { Experimental production } \\
(\mu \mathrm{g} / \mathrm{g} / 3 \mathrm{~h})\end{array}$ & $\begin{aligned} & 15 \cdot 6 \\
\pm & 2 \cdot 9^{*}\end{aligned}$ & $\begin{array}{c}7 \cdot 0 \\
\pm 0 \cdot 8^{* *}\end{array}$ & $\begin{array}{c}12 \cdot 7 \\
\pm 2 \cdot 4^{* *}\end{array}$ & $\begin{array}{r}14 \cdot 9 \\
\pm 4 \cdot 1\end{array}$ & $\begin{array}{c}7.8 \\
\pm 0.7^{* *}\end{array}$ & $\begin{array}{c}7.0 \\
\pm 1 \cdot 3^{*}\end{array}$ & $\begin{array}{l}10 \cdot 6 \\
\pm 4 \cdot 3\end{array}$ & $\begin{array}{r}4.2 \\
+1.8\end{array}$ & $\begin{array}{r}2.6 \\
\pm 0.4\end{array}$ \\
\hline Oestradiol & & & & & & & & & \\
\hline Original content $(\mathrm{ng} / \mathrm{g})$ & $\begin{array}{c}570 \\
\pm 265\end{array}$ & $\begin{array}{c}531 \\
\pm 139\end{array}$ & $\begin{array}{l}281 \\
\pm 67\end{array}$ & $\begin{array}{l}165 \\
\pm 35\end{array}$ & $\begin{array}{c}536 \\
\pm 154\end{array}$ & $\begin{array}{c}290 \\
\pm 110\end{array}$ & $\begin{array}{c}540 \\
\pm 340\end{array}$ & $\begin{array}{l}285 \\
\pm 64\end{array}$ & $\begin{array}{l}280 \\
\pm 86\end{array}$ \\
\hline $\begin{array}{l}\text { Control production } \\
(\mathrm{ng} / \mathrm{g} / 3 \mathrm{~h})\end{array}$ & $\begin{array}{c}932 \\
\pm 332\end{array}$ & $\begin{array}{l}149 \\
\pm 37\end{array}$ & $\begin{array}{c}82 \\
\pm 19\end{array}$ & $\begin{array}{l}118 \\
\pm 27\end{array}$ & $\begin{array}{l}113 \\
\pm 46\end{array}$ & $\begin{array}{l}106 \\
\pm 23\end{array}$ & $\begin{array}{c}278 \\
\pm 126\end{array}$ & $\begin{array}{l}123 \\
\pm 42\end{array}$ & $\begin{array}{c}91 \\
\pm 20\end{array}$ \\
\hline $\begin{array}{l}\text { Experimental production } \\
(\mathrm{ng} / \mathrm{g} / 3 \mathrm{~h})\end{array}$ & $\begin{array}{l}2236 \\
\pm 536\end{array}$ & $\begin{array}{c}453 \\
\pm 78^{*}\end{array}$ & $\begin{array}{c}391 \\
\pm 125^{*}\end{array}$ & $\begin{array}{r}556 \\
\pm 89^{*}\end{array}$ & $\begin{aligned} & 652 \\
\pm & 113^{* *}\end{aligned}$ & $\begin{array}{c}457 \\
\pm 70^{*}\end{array}$ & $\begin{aligned} & 1242 \\
& \pm 449^{*}\end{aligned}$ & $\begin{array}{r}396 \\
\pm 85^{*}\end{array}$ & $\begin{array}{l}279 \\
\pm 50\end{array}$ \\
\hline
\end{tabular}

Values are mean \pm s.e.m.

Values significantly different from the control value are indicated: ${ }^{*} P<0.05,{ }^{* *} P<0.01$ (paired $t$ test).

When CL were incubated with dibutyryl cAMP progesterone production was significantly stimulated during the mid- and late luteal phase, and control synthesis was greatest during the early luteal phase (Table 1). Oestradiol production was stimulated in all ages of tissue.

Incubation with FSH led to no significant enhancement of progesterone production but oestradiol production was significantly stimulated during the early and mid-luteal phases.

\section{Discussion}

The results of the present study show that while hCG and cAMP can stimulate progesterone and oestradiol synthesis by the human corpus luteum, FSH stimulated oestradiol production only. This indicates that the synthesis of these two steroids can be independently controlled. Because the steroids were determined in both the tissue and media after incubation (and original concentration in the tissue subtracted), the values did represent synthesis and not merely release into the medium.

The ability of hCG to stimulate steroid synthesis during the late luteal phase was of interest because this is the time when the CL is 'rescued' by hCG if pregnancy occurs. The large variation in steroid production within and between $\mathrm{CL}$ was probably due to blood and non-luteal cells affecting the wet weight of the tissue, and by the slightly different ages of CL within each category. Nevertheless, in all groups the early luteal tissue consistently synthesized the most progesterone and oestradiol on a tissue weight basis during control incubations.

It is now widely accepted that hCG acts via cAMP (Marsh \& LeMaire, 1974) and the addition of dibutyryl cAMP to the incubations stimulated steroid production during most of the stages. Similar responses were also produced by human $\mathrm{LH}(20 \mathrm{mu} / \mathrm{ml})$ in the medium (Hunter, 1980). The concentration of FSH used in these incubations was chosen as a physiological dose in relation to blood concentrations of FSH during the menstrual ${ }_{\circ}$ cycle $_{\text {(Midgley }} \&_{4} \mathrm{Jaffe}_{2} 2 \mathrm{~J}_{2}$ (968; 
Mishell et al., 1971; Abraham, Odell, Swerdloff \& Hopper, 1977). FSH has been reported to have no effect on steroidogenesis by the corpus luteum (Rice et al., 1964; Savard et al., 1965), but this may have been because only progesterone levels were examined as the end product. Estimation of the vacant FSH receptors in the human CL has shown these to be most numerous during the early luteal phase (McNeilly, Kerin, Swanston, Bramley \& Baird, 1980). The failure of FSH to enhance oestradiol synthesis significantly during the late phase although hCG and cAMP are stimulatory may be due to declining receptor populations and sensitivity of the cells.

We conclude that both hCG and FSH play a role in the control of steroid synthesis by the human corpus luteum as well as the follicle.

The expenses incurred in this study were defrayed out of a grant to T.G.B. by the Ford Foundation (760-0532). We thank the gynaecologists of the Royal Infirmary, Edinburgh, for the supply of tissue.

\section{References}

Abraham, G.E. (1974) Ovarian and adrenal contribution to peripheral androgens during the menstrual cycle. J. clin. Endocr. Metab. 39, 340-356.

Abraham, G.E., Odell, W.D., Swerdloff, R.S. \& Hopper, K. (1977) Simultaneous radioimmunoassay of FSH, LH, progesterone, 17-hydroxyprogesterone and oestradiol-17 $\beta$ during the menstrual cycle. J. clin. Endocr. Metab. 34, 312-318.

Armstrong, D.T. \& Dorrington, J.H. (1977) Estrogen biosynthesis in the ovaries and testes. Adv. Sex Horm. Res. 3, 217-258.

Baird, D.T. \& Fraser, I. (1974) Blood production and ovarian secretion rates of estradiol- $17 \beta$ and estrone in women through-out the menstrual cycle. J. clin. Endocr. Metab. 38, 1009-1017.

Baird, D.T., Baker, T.G., McNatty, K.P. \& Neal, P. (1975) Relationship between the secretion of the corpus luteum and the length of the follicular phase in ovarian cycles. J. Reprod. Fert. 45, 611-619.

Corner, G.W., Jr (1956) The histological dating of the corpus luteum of menstruation. Am. J. Anat. 98, $377-401$.

Dell'Acqua, S., Serra, G.B., Lucisano, A., Montemurro, A., Cinque, B., Amo, E. \& Bompiani, A. (1976) Release of $\mathrm{C} 21, \mathrm{C} 19$ and $\mathrm{C} 18$ steroids by human ovaries stimulated in vivo by hCG. In The Endocrine Function of the Human Ovary, pp. 427-436. Eds V. H. T. James, M. Serio \& G. Guisti. Academic Press, London.

Eagle, H. (1959) Amino acid metabolism in mammalian cell cultures. Science, N.Y. 130, 432-437.

Erickson, G.F. \& Hsueh, A.J.W. (1978) Induction of aromatase activity by follicle stimulating hormone in rat granulosa cells in vivo and in vitro. Endocrinology 102, 1275-1282.

Hammerstein, J., Rice, B.F. \& Savard, K. (1964) Steroid formation in the human ovary. 1. Identification of steroids formed in vitro from ${ }^{14} \mathrm{C}$-acetate in the corpus luteum. J. clin. Endocr. Metab. 24, 597-605.

Hunter, M.G. (1980) Studies on the corpus luteum in vitro. Ph.D. thesis, University of Edinburgh.

Marsh, J.M. \& LeMaire, WJ. (1974) Cyclic AMP accumulation and steroidogenesis in the human corpus luteum: effect of gonadotrophins and prostaglandins. J. clin. Endocr. Metab. 38, 99-106.
McNeilly, A.S., Kerin, J., Swanston, I.A., Bramley, T.A. \& Baird, D.T. (1980) Changes in the binding of human chorionic gonadotrophin-luteinizing hormone, follicle stimulating hormone and prolactin to human corpora lutea during the menstrual cycle and pregnancy. J. Endocr. 87, 315-326.

Midgley, A.R., Jr \& Jaffe, R. (1968) Regulation of human gonadotrophins. IV. Correlation of serum concentrations of follicle stimulating and luteinizing hormones during the menstrual cycle. J. clin. Endocr. Metab. 28, 1699-1703.

Mikhail, G. (1970) Hormone secretion by the human ovaries. Gynecol. Invest. 1, 5-20.

Mishell, D.R., Nakamura, R.M., Crosignani, P.G., Stone, S., Kharma, K., Nagata, Y. \& Thorneycroft, I.H. (1971) Serum gonadotrophin and steroid patterns during the normal menstrual cycle. Am. J. Obstet. Gynec. 111, 60-63.

Moon, Y.S., Dorrington, J.H. \& Armstrong, D.T. (1975) Stimulatory action of follicle stimulating hormone on estradiol-17 $\beta$ secretion by hypophysectomized rat ovaries in organ culture. Endocrinology 97, 244-247.

Rice, B.F., Hammerstein, J. \& Savard, K. (1964) Steroid hormone formation in the human ovary. 11. Action of gonadotrophins in vitro in the corpus luteum. $J$. clin. Endocr. Metab. 24, 606-615.

Santos, A.A. \& Hermier, C. (1973) Mecanisme d'action de la gonadotrophine chorionique (hCG) dans le corps jaune humaine. In Le Corps Jaune, pp. 297-309. Eds R. Denamur \& A. Netter. Masson et Cie, Paris.

Savard, K., Marsh, J. M. \& Rice, B. F. (1965) Gonadotrophins and ovarian steroidogenesis. Recent Prog. Horm. Res. 21, 285-365.

Scaramuzzi, R.J., Corker, C.S., Young, G. \& Baird, D.T. (1975) Production of antisera to steroid hormones in sheep. In Steroid Immunoassay, pp. 111-122. Eds E. H. D. Cameron, S. G. Hillier \& K. Griffiths. Alpha Omega Alpha, Cardiff.

Vande Wiele, R.L., Bogumil, J., Dyrenfurth, I., Ferin, M., Jewelewicz, R., Warren, M., Rizkallah, T. \& Mikhail, G. (1970) Mechanisms regulating the menstrual cycle in women. Recent Prog. Horm. Res. 26, 63-103.

Received 5 November 1980 